\title{
ILMU PENDIDIKAN YANG BERAKAR DARI ANTROPOLOGI, SOSIOLOGI DAN PSIKOLOGI
}

\author{
Oleh :Prof. Dr. Firman. MS. Kons \\ (Fakultas Ilmu Pendidikan Univ.Negeri Padang) \\ Email : firman@konselor.org
}

\section{A. Pendahuluan}

Pendidikan dalam bahasa Yunani diistilahkan dengan pedagogik. Pedagogik atau ilmu pendidikan adalah ilmu yang mebicarakan masalah-masalah umum pendidikan yang bersifat teoris dan praktis. Conny Semiawan (2007) menjelaskan tidak jarang dalam kehidupan sehari-hari ilmu pendidikan secara esensial kurang dipahami, karena kenyataan pendidikan itu bersifat ganda, yaitu berupa pengalaman pendidikan dan objektivitasnya (objectification) sebagai phaenomenon bene fundamentation yang sifatnya multi-referensial, berakar dari psikologi, sosiologi, filsafat dan antropologi.

Pengenalan peserta didik dengan potensi serta kebutuhannya dalam praktek pendidikan memerlukan pemahaman dari berbagai sudur padang ilmu perilaku, diantaranya: Sosiologi, antropologi dan psikologi. Pemahaman perilaku peserta didik beserta masyarakat dan latar budayanya sangat bermanfaat dalam pelaksanaan pembelajaran di sekolah maupun luar sekolah. Melalui makalah ini akan dikaji lebih lanjut bagaimana pendidikan sebagai ilmu dalam kajian psikologi, sosiologi dan antropologi.

\section{B. Ilmu Pendidikan sebagai Ilmu}

Pedagogik sebagai landasan utama dalam praktek pendidikan memerlukan landasan konsep dan fungsi yang berasal dari filsafat. Secara filosofis pendidikan 
sebagai ilmu mempunyai objek kajian formal dan material. Mohammad Noor Syam (1986:23) menjelaskan objek material ilmu pengetahuan amat terbatas dan tertentu. Demikian pula objek formal, sudut pandang, tujuan ilmu pengetahuan tertentu pula. Objek material ilmu pendidikan adalah manusia. Sehubungan dengan hal itu, objek material ilmu pendidikan sama dengan psikologi, ilmu ekonomi, sosiologi, ilmu kesehatan, yaitu manusia.

Perbedaan kajian diantara bidang ilmu tersebut, terletak pada objek formalnya. Objek formal filsafat adalah menyelidiki segala sesuatu guna mengerti hakekatnya sedalam-dalamnya. Dengan arti kata mengerti objek materialnya ilmu secara hakiki dan kodrat segala sesuatu secara mendalam. Berkaitan dengan hal itu, Mohammad Noor Syam (1986:23) menjelaskan objek material dan formal ilmu pendidikan dapat dijelaskan sebagai berikut:

\begin{tabular}{|c|c|c|c|}
\hline NO. & ILMU & OBJEK MATERIAL & OBJEK FORMAL \\
\hline 1. & Psikologi & \multirow{5}{*}{ MANUSIA } & Tingkah laku \\
\hline 2. & Ekonomi & & $\begin{array}{l}\text { Kebutuhan dan cara } \\
\text { memenuhinya }\end{array}$ \\
\hline 3. & Sosiologi & & Antar hubungan sosial \\
\hline 4. & Kesehatan & & Kondisi-kondisi kehidupan \\
\hline 5. & Pendidikan & & Pembinaan kepribadian \\
\hline
\end{tabular}

Pendidikan sangat menentukan proses perkembangan manusia. Di zaman moderen ini, sebagai sesuatu kekuatan yang menentukan proses pendidikan yang diperoleh individu di lingkungan formal, non formal dan informal adalah prestasi dan 
produktifitas. Dalam arti luas Richey (Mohammad Noor Syam, 1986 :53) menjelaskan istilah pendidikan berkenaan dengan fungsi yang luas dari pemeliharaan dan perbaikan kehidupan suatu masyarakat terutama generasi muda dalam menunaikan kewajiban dan tanggung jawabnya di dalam masyarakat. Jadi pendidikan adalah suatu proses yang lebih luas dari proses yang berlangsung di sekolah. Pendidikan adalah suatu proses sentral dan esensial yang memungkinkan masyarakatat tetap ada dan berkembang. Didalam masyarakat yang komplek atau moderen, pendidikan mengalami proses spesialisasi dan melembaga dengan pendidikan formal dan tetap berhubungan dengan pendidikan informal serta non formal.

Undang-undang no 20 tahun 2003 tentang Sisdiknas, pasal 1 ayat 1 menjelaskan: Pendidikan adalah usaha sadar dan terencana untuk mewujudkan suasana belajar dan proses pembelajaran agar peserta didik secara aktif mengembangkan potensi dirinya untuk memiliki kekuatan spiritual keagamaan, pengendalian diri, kepribadian, kecerdasan, akhlak mulia, serta keterampilan yang diperlukan dirinya, masyarakat, bangsa dan negara.

Sehubungan dengan hal itu, dapat disimpulkan bahwa setiap pribadi manusia terlibat menerima pengaruh sebagai akibat dari proses pendidikan dalam arti luas. Kenyataannya manusia sekaligus warga masyarakat dan pendidikan juga berlangsung di dalam masyarakat. Oleh karena itu pendidikan seharusnya merupakan proses penggalian dan pengembangan segenap potensi peserta didik melalui usaha sadar dan terencana untuk berkembang secara optimal. Proses ini diarahkan untuk mewujudkan suasana belajar dan proses pembelajaran agar peserta didik secara aktif 
mengembangkan potensi dirinya untuk memiliki kekuatan spiritual keagamaan, pengendalian diri, kepribadian, kecerdasan, akhlak mulia, serta keterampilan yang diperlukan dirinya, masyarakat, bangsa dan negara.

Dengan demikian ruang lingkup pendidikan meliputi seluruh umat manusia, sepanjang sejarah adanya manusia dan sepanjang hidup manusia. Bagian yang dipelajari ilmu pendidikan terhadap manusia tidak hanya mempelajari konsep tingkah laku manusia yang dapat diamati secara nyata, melainkan mencakup konsep tindakan dalam kehidupan manusia menuju ke arah perubahan yang lebih baik. Conny Semiawan (2007) menjelaskan ilmu pendidikan merupakan ilmu yang mempelajari perilaku inanusia dalam pembinaan kepribadinnya ke arah lebih baik.

\section{B. Pendidikan dalam Kajian Psikologi.}

Perbedaan kajian formal antara psikologi dan ilmu pendidikan, maka materi yang digarap ilmu pendidikan berbeda dengan psikologi. Kajian psikologi cenderung lebih bersifat empiris, yaitu perilaku individu beserta latar belakangnya. Sedangkan ilmu pendidikan lebih cenderung mengkaji perilaku yang normatif yang diperuntukkan bagi praktek pendidikan.

Pemahaman perilaku individu dalam proses pendidikan memelukan kajian psikologi. Seorang pendidikan tanpa memahami psikologi secara baik tidak dapat melaksanakan pembelajaran sesuai dengan kebutuhan dan perkembangan peserta didik. Begitu juga dalam hal perencanaan, proses serta evaluasi pembelajaran. Salah satu kegagalan guru dalam melaksanakan pembelajaran bersumber dengan minimnya pemahaman psikologis terhadap peserta didik. 
Sebagai makhluk sosial dituntut beradaptasi, mentaati berbagai aturan yang berlaku dalam masyarakat dimana mereka berada. Di sisi lain, sebagai makhluk individu mereka mempunyai hak bertumbuh dan berkembang serta mengaktualisasikan diri. Perubahan tingkah laku yang dialami individu untuk mengaktualisasikan dirinya sebagai akibat dari proses pembelajaran yang dijalaninya melalui pendidikan formal, informal dan nonformal.

Cony Semiawan (2007) menjelaskan ilmu pendidikan tidak hanya merpelajari konsep tingkahlaku manusia, sebagai objek yang dapat diamati secara nyata, melainkan mencakup konsep tindakan (action concept) manusiawi yang mengandung subjektivitas, intersubjektivitas dan intensionalitas, merefleksikan human spirit yang mengacu ke masa depan.

Dengan demikian dapat simpulkan perbedaan kajian formal antara psikologi dengan pendidikan berbeda menyebabkan materi yang digarap kedua bidang ilmu tersebut berbeda. Kajian psikologi cenderung lebih bersifat empiris, yaitu perilaku individu beserta latar belakangnya. Sedangkan ilmu pendidikan lebih cenderung mengkaji perilaku yang normatif yang diperuntukkan bagi praktek pendidikan.

\section{Pendidikan dalam Kajian Antropologi dan Sosiologi.}

Kajian ilmu pendidikan berbeda dengan sosiologi dan antropologi, karena kajian formal masing ilmu tersebut berbeda. Ke tiga bidang ilmu sama-sama mengkaji perilaku manusia, psikologi mengkaji perilaku individu beserta latar belakangnya secara emperis. Sosiologi mengkaji antar hubungan sosial dalam masyarakat, sedangkan antropologi mengkaji manusia dan kebudayaannya. 
Pendidikan membentuk fikiran, karakter atau kapasitas fisik seseorang yang berlangsung seumur hidup. Sehubungan dengan hal itu, pengenalan cara berfikir dan bertindak yang baru membawa setiap perubahan besar dalam kehidupan. Generasi muda tidak akan matang secara budaya tanpa diasuh menjadi dewasa. Sehubungan dengan itu, penyampaian kebudayaan melalui proses transmisi kebudayaan dari satu generasi ke generasi berikut. Masyarakat selalu mengawasi pendidikan dari anggotanya mulai dari masa anak-anak di lingkungan pendidikan formal, informal maupun nonformal.

Kebudayaan sebagai kajian dalam antropologi dapat dimaknai sebagai fenomena material, ehingga menurut perspektip ini pemahaman dan pemaknaan kebudayaan lebih banyak dicermati sebagai keseluruhan sistem gagasan, tindakan dan hasil karya manusia dalam rangka kehidupan masyarakat yang dijadikan milik diri manusia sebagai hasil dari belajar (Koentjaraningrat, $1980: 193$ ). Sejalan dengan pengertian tersebut maka tingkah laku manusia sebagai anggota masyarakat akan terikat oleh kebudayaan yang terlihat wujudnya dalam berbagai pranata yang berfungsi sebagai mekanisme kontrol bagi tingkah laku manusia (Geertz, 1973).

Penggalian potensi individu serta kebutuhannya berdasarkan masyarakat dan kebudayaan sangat diperlukan, sehingga peserta didik tidak merasa terasing dengan masyarakat dan budayanya setelah menjalani proses pendidikan di lingkungan formal, nonformal dan informal. Pada gilirannya peserta didik sebagai aktor dalam perubahan sosial dan kebudayaan akan dapat mengembangkan budaya mereka sendiri sebagai akibat dari proses pembelajaran yang dijalaninya. Antropologi dapat memberikan sumbangan kepada ilmu pendidikan berkaitan dengan cara mempelajari implikasi 
pendidikan berdasarkan kebudayaan. Kajian lintas budaya mengenai pendidikan akan memungkinkan para pendidik mempelajari pengalaman kebudayaan lain dan menilik sekolahnya sendiri.

Keharusan pengembangan pendidikan seringkali diungkapkan dengan menyatakan bahwa pendidikan akan membuka pintu menuju ke dunia moderen, karena dengan pendidikan dapat dilakukan perubahan sosial budaya, yaitu pengembangan ilmu pengetahuan, penyesuaian nilai-nilai dan sikap yang mendukung pembangunan serta penguasaan berbagai keterampilan dalam menggunakan teknologi maju untuk mempercepat proses pembangunan dalam masyarakat.

Masyarakat moderen adalah masyarakat yang menganut orientasi nilai yang menggutamakan penilaian berdasarkan achievement yang bukan status. Mc Clelland (Imran Manan, 1989:680) menjelaskan pendidikan anak-anak yang menekankan percaya diri sendiri, kebebasan dan persaingan yang sehat akan menghasilkan orangorang dewasa yang mempunyai kepribadian berorientasi keberhasilan sehingga mendorong muncul entrepreneurial personality. Keperibadian wiraswasta secara sederhana mempunyai ciri: Suka bertanggungjawab atas pekerjaannya, suka bekerja dengan hasil yang jelas yang dapat diukur dengan sukses atau gagal, bekerja dengan rencana dan berani mengambil resiko yang diperhitungkan.

Dalam penyelesaian permasalahan pendidikan, kenyataannya mempelajari konsep psikologi, seperti interaksi sosial dalam pembelajaran bukan hanya dapat dibahas secara psikologis. Sosiologi dan antropologi juga dapat mempelajari interaksi sosial dalam pembelajaran. Pemahaman kajian formal masing-masing keilmuan dalam praktek pendidikan sangat diperlukan dalam mencapai sasaran utama 
pendidikan, yaitu pengembangan potensi peserta didik sebagai anggota masyarakat, bangsa dan negara.

Masyarakat dan kebudayaan pada dasarnya merupakan pola kehidupan bersama antara individu-individu manusia yang bersifat dinamis. Masyarakat majemuk memiliki banyak kebudayaan dengan standar perilaku yang berbeda dan kadangkala bertentangan. Perkembangan kepribadian individu pada masyarakat tersebut sering dihadapkan pada model-model perilaku disetujui oleh beberapa kelompok namun dicela atau dikutuk oleh kelompok lainnya.

Individu yang sedang berkembang akan belajar dari kondisi yang ada, sehingga kepribadian mereka berkembang. Pola asuh dalam keluarga sangat berperan dalam pembentukan kepribadian. Satu hal pokok yang perlu dipahami adalah pengalaman seseorang tidak hanya sekedar bertambah dalam proses pembentukan kepribadian, namun terintegrasi dengan pengalaman sebelumnya. Pada dasarnya kepribadian yang memberikan corak khas pada perilaku dan pola penyesuaian diri, tidak dibangun dengan menyusun suatu peristiwa atas peristiwa lain, karena arti dan pengaruh suatu pengalaman tergantung pada pengalaman-pengalaman yang mendahuluinya.

Masyarakat Indonesia yang terdiri dari berbagai budaya secara logis akan mengalami berbagai permasalahan, persentuhan antar budaya akan selalu terjadi karena permasalahan silang budaya selalu terkait erat dengan pola pikir dan tindakan dari kelompok sosial tertentu. Nilai-nilai yang terkandung dalam kebudayaan menjadi acuan sikap dan perilaku manusia sebagai makhluk individual yang tidak terlepas dari kaitannya dengan kehidupan masyarakat. 


\section{Kesimpulan}

Berdasarkan uraian tersebut dapat disimpulkan

1. Setiap bidang ilmu mempunyai kajian formal dan material tersendiri. Ilmu pendidikan, sosiologi dan natropologi mengkaji manusia sebagai kajian materialnya. Sedangkan kajian formal formal masing-masing ilmu tersebut berbeda.

2. Ilmu pendidikan mengkaji segala sesuatu yang berkaitan dengan konsep tindakan dalam kehidupan manusia menuju ke arah perubahan yang lebih baik dan berguna bagi diri sendiri, orang lain serta masyarakat sekitar.

3. Psikologi cenderung lebih bersifat empiris dan mengkaji perilaku individu beserta latar belakangnya. Pemahaman psikologi sangat diperlukan dalam pelaksanaan pendikan guna memahami perkembangan serta kebutuhan individu yang sedang menjalani pendidikan.

4. Sosiologi mengkaji antar hubungan sosial dalam masyarakat, sedangkan antropologi mengkaji manusia dan kebudayaannya. Masyarakat dan kebudayaan pada dasarnya merupakan pola kehidupan bersama antara individu-individu manusia yang bersifat dinamis. 


\section{Daftar Pustaka}

Cony Semiawan (2007) : Perkembangan Ilmu Pendidikan pada Era Globalisasi dan Implikasinya terhadap Peningkatan Mutu pendidikan (dalam rangka Studium General Fakulktas Ilmu Pendidikan Universitas Negeri Padang) (makalah). Padang : FIP UNP.

Imran Manan (1989) : Antropologi Pendidikan Suatu Pengantar. Jakarta :

Departemen Pendidikan dan Kebudayaan Direktorat Jenderal Pendidikan Tinggi.

Imran Manan (1989) : Dasar-dasar Sosial Budaya Pendidikan. Jakarta : Departemen Pendidikan dan Kebudayaan Direktorat Jenderal Pendidikan Tinggi.

Imam Barnadib (1990) : Filsafat Pendidikan (Pengantar Mengenai dan Metode). Yogyakarta : Penerbit Andi Offset Yogyakarta.

Mohammad Noor Syam (1986) : Filsafat Kependidikan dan Dasar Filsafat Kependidikan Pancasila. Surabaya : Usaha Nasional. 
MAKALAH

\section{ILMU PENDIDIKAN YANG BERAKAR DARI ANTROPOLOGI, SOSIOLOGI DAN PSIKOLOGI}

Oleh : Prof. Dr. Firman. MS. Kons

(FIP Univ.Negeri Padang)

Disampaikan Dalam Seminar Internasional Pendidikan dan Temu Karya Dekan FIP/FKIP BKS-PTN Wilayah Barat Indonesia dengan Tema Membangun Sumber Daya Manusia yang Berkualitas Melalui Peningkatan Profesionalisasi Pendidik dan Tenaga Kependidikan Pada Tanggal 7-9 November 2008

Di Plaza Roxy Hotel Padang 
